\title{
Cytoarchitecture of the superior olivary complex of three neotropical species of bats (Noctilio leporinus, Phyllostomus hastatus and Carollia perspicillata) with different foraging behavior
}

\author{
I. Gibbons ${ }^{a}$ (D), V. Sundarama* (D), A. Adogwa ${ }^{a}$ (D) and A. Odekunle (D) $^{a}$ \\ ${ }^{a}$ Department of Basic Veterinary Sciences, School of Veterinary Medicine, Faculty of Medical Sciences, \\ The University of the West Indies, St. Augustine, Trinidad and Tobago \\ ${ }^{\mathrm{b}}$ Anatomy Unit, Department of Preclinical Sciences, School of Medicine, Faculty of Medical Sciences, \\ The University of the West Indies, St. Augustine, Trinidad and Tobago \\ *e-mail: drvenkat1971@gmail.com
}

Received: August 3, 2018 - Accepted: November 23, 2018 - Distributed: February 28, 2020

(With 3 figures)

\begin{abstract}
The understanding of the echolocation by studying different auditory nuclei of echolocating bats can be an important link in elucidating questions arising in relation to their foraging behavior. The superior olivary complex (SOC) is the primary center for processing the binaural cues used in sound localization since echo locating bats rely on acoustic cues to navigate and capture prey while in flight. The present study was taken to test the hypothesis that the SOC of echolocating neotropical bats with different foraging behavior will exhibit morphological variations in relative size, degree of complexity and spatial distribution. The brains were collected from six male adult bats of each species: Noctilio leporinus (fish eating), Phyllostomus hastatus (carnivorous/omnivorous) and Carollia perspicillata (fruit eating). They were double-embedded and transverse serial sections were cut and stained with cresyl fast violet. The SOC measured as $640 \pm 70 \mu \mathrm{m}$ in the $N$. leporinus bat, $480 \pm 50 \mu \mathrm{m}$ in the P. hastatus and $240 \pm 30 \mu \mathrm{m}$ in the C. perspicillata bat. The principal nuclei of the SOC of in all three bats were the LSO, MSO and MNTB. The MSO and LSO were very well developed in N. leporinus bats. The MSO of $N$. leporinus bat subdivided into DMSO and VMSO. The main cell type of cells present in MSO and LSO are dark staining multipolar cells in all the bats studied. The well-developed MSO and LSO of $N$. leporinus bats indicate that these bats are highly sensitive to low frequency sounds and interaural intensity differences, which help these bats to forage over water by using various types of echolocation signals. The average size of SOC in P. hastatus and C. perspicillata bats can be attributed to the fact that these bats use vision and smell along with echolocation to forage the food.
\end{abstract}

Keywords: bats, superior olivary complex, medial superior olive, lateral superior olive.

\section{Citoarquitetura do complexo olivar superior de três espécies neotropicais de morcegos (Noctilio leporinus, Phyllostomus hastatus e Carollia perspicillata) com diferentes comportamentos de forrageamento}

\begin{abstract}
Resumo
O entendimento da ecolocalização pelo estudo de diferentes núcleos auditivos de morcegos pode ser um elo importante na elucidação das inúmeras questões que surgem em relação ao seu comportamento de forrageamento. O complexo olivar superior (SOC) é o principal centro de processamento das pistas binaurais usadas na localização do som, já que os morcegos ecolocalizadores contam com sinais acústicos para navegar e capturar as presas durante o vôo. O presente estudo foi realizado para testar a hipótese de que morcegos que usam a ecolocalização para diferentes comportamentos de forrageamento irão variar na estrutura, tamanhos relativos e grau de complexidade e distribuição espacial do grupo SOC. Os cérebros foram coletados de seis machos adultos de morcego de cada espécie: Noctilio leporinus (piscívoro), Phyllostomus hastatus (carnívoros/onívoros) e Carollia perspicillata (frugívoro). Eles foram seccionados em série e transversalmente, cortados e corados com coloração rápida cresil-violeta. tolet. O grupo SOC foi medido como $640 \pm 70 \mu \mathrm{m}$ no morcego $N$. leporinus, $480 \pm 50 \mu \mathrm{m}$ no P. hastatus e $240 \pm 30 \mu \mathrm{m}$ no morcego C. perspicillata. Os principais núcleos do grupo SOC dos três morcegos foram o LSO e o MSO e o MNTB. O MSO e o LSO foram muito bem desenvolvidos em morcegos $N$. leporinus. A MSO de $N$. leporinus foi subdividida em DMSO e VMSO. O principal tipo de células presentes na MSO e LSO são as células multipolares de coloração escura em todos os morcegos. Os MSO bem desenvolvidos e LSO de morcegos $N$. leporinus indicam que estes morcegos são
\end{abstract}


altamente sensíveis a sons de baixa frequência e diferenças de intensidade interaural, que ajudaram estes morcegos a se alimentarem na superfície da água usando vários tipos de sinais de ecolocalização. O tamanho médio de SOC em morcegos de $P$. hastatus e $C$. perspicillata pode ser atribuído ao fato destes morcegos usarem visão e olfato junto com a ecolocalização para forragear.

Palavras-chave: morcegos, complexo olivar superior, oliva superior medial, oliva superior.

\section{Introduction}

The superior olivary complex (SOC) is a well-developed auditory brainstem structure in all mammals including echolocating bats. The SOC plays a number of roles in hearing including the localization of sound resources, measuring the time difference of arrival of sounds between the ears, encoding temporal features of sounds and descending modulation of cochlear nucleus (Grothe and Park, 2000). The SOC is typically located in the caudal brainstem near the facial nucleus and consists of up to 13 distinct cell groups, each contributing a unique neuronal circuit and sub serving a distinct functional role in the processing of sound (Schofield, 2002). The SOC consists of two principal nuclei, the medial superior olive (MSO) and the lateral superior olive (LSO) with established roles in hearing. The principal cell groups are flanked by a population of peri-olivary nuclei whose functional contributions are poorly understood.

The MSO and LSO are a major site of convergence of information arising from both cochlear nuclei (Glendenning et al., 1985). The MSO neurons are binaural, most sensitive to low-frequency sounds (at or below $5 \mathrm{kHz}$ ) and encode interaural timing differences (Spitzer and Semple, 1995) and LSO neurons are binaural and sensitive to interaural intensity differences (Sanes, 1990). The LSO is most prominent in animals with excellent high-frequency hearing, especially those utilizing echolocation (Zook and Casseday, 1982; Glendenning and Masterton, 1998). Recently however, it has been speculated that the size of the LSO is more indicative of the animal's overall hearing range rather than sensitivity to high-frequency sounds (Moore, 2000).

Many bats use echolocation for orientation in space and for detecting and capturing prey in total darkness (Genoud et al., 1990; Webster et al., 1992; Bailey et al., 1992). The echolocating bats use different echolocating strategies based on their foraging environment. The vast majority of echolocating bats emit very short (0.5-5.0 ms) frequency modulated (FM) sweeps, covering a large proportion of their hearing range. The FM echoes returning from flying insects carry information about the range and location of those targets. In contrast to the FM bats, other bats such as horseshoe bats and mustached bats independently developed an echolocation strategy using a combination of a long constant frequency component (CF), and a brief FM sweep. The use of CF-FM echolocation calls allows these bats to segregate different aspects of information. The echo from the FM sweep is used for ranging and localization, while Doppler shifts in the echo from the CF component carry information about the relative velocity of the bat to a target. In addition, the amplitude and frequency modulations imposed on the echo of the CF component by an insect's wing beating allow the bat to identify specific insect species (Von der Emde and Schnitzler, 1990) and to distinguish fluttering prey from non-fluttering background, even in a densely cluttered environment.

The similarities and differences that will be exhibited in the SOC of bats with different echolocation strategies can be useful in understanding the principal problems of what aspects of sound different SOC nuclei process and what some of the underlying mechanisms and circuitry patterns are in the SOC. The information on the comparative analysis of structure and cytoarchitecture of SOC associated with echolocating bats with different foraging strategies seems to be lacking.

The three species of Neotropical bats viz., Noctilio leporinus Linnaeus 1758, Phyllostomus hastatus Pallas 1767 and Carollia perspicillata Linnaeus 1758 were chosen based on their differing foraging behavior for the present study. The living range of these bats stretches from Mexico to Northern Argentina and also includes most Caribbean islands. The $N$. leporinus belongs to the Noctilionidae family whereas both $P$. hastatus and $C$. perspicillata belongs to Phyllostomidae family. The $N$. leporinus bats lives mostly around well-watered lowland and coastal areas as well as river basins. They eat small fish in both fresh and salt water but they need calm water surfaces in order to detect ripples. P. hastatus bats are omnivores, feeding on flowers and pollen, but also insects and small vertebrates, forage on open and forested regions. C. perspicillata bats are mainly frugivorous. However, they may feed on insects and sometimes pollen, which forage on moist evergreen and dry deciduous forests. Therefore, the present study is undertaken to provide comparative structural and cytoarchitectural details of the SOC of three species of bats with different foraging behavior.

\section{Material and Methods}

For the present study, six adult male live bats of each of the three species, $N$. leporinus, $P$. hastatus and C. perspicillata were collected. The bats were weighed and anaesthetized by using xylazine $2 \mathrm{mg} / \mathrm{kg}$ and ketamine $10 \mathrm{mg} / \mathrm{kg}$ intramuscularly. The research protocol was approved by the institutional ethical committee. Immediately after euthanasia, the brains of the bats were removed, weighed and placed in $10 \%$ formal saline. The brains were manually processed and double embedded (Gibbons et al., 2013a, b). The tissues were then blocked and coronal sections at $10 \mu \mathrm{m}$ were made by using the rotary microtome MT 960. The sections were stained using Cresyl Fast violet. The size, shape and orientation of the cells were analyzed with the aid of the Olympus BX51 system microscope and the digital images were taken with the help of Olympus DP71 microscope digital camera. 


\section{Results}

\subsection{Superior olivary complex of the Noctilio leporinus bat}

At the most caudal level, the SOC first becomes apparent at the level of facial nucleus (see Figure 1A). The facial nucleus was easily distinguished by a large cell group containing homogenous population of relatively large multipolar neurons. Lateral to the facial nucleus, the SOC comprised of mainly dense-staining multipolar neurons measuring between 12.5 to $17.5 \mu \mathrm{m}$ in diameter. In addition, few light-staining, round cells with a diameter of $7.5 \mu \mathrm{m}$ were present. Dense-staining, oval cells measuring $5 \mu \mathrm{m}$ in diameter were also present but very few in numbers. The SOC measured $500 \pm 55 \mu \mathrm{m}$ at its widest point, medio-laterally. Overall, the SOC extends rostrally the mid-pons and measured $640 \pm 70 \mu \mathrm{m}$ in length.
Progressing rostrally, the caudal third of the SOC divided into two main portions: medial superior olive (MSO) and lateral superior olive (LSO) (see Figure 1B). The LSO is the larger of the two. It contained a folded region medially and this allowed for the further differentiation of LSO into two portions. The LSO measured $850 \pm 70 \mu \mathrm{m}$ in height and $640 \pm 85 \mu \mathrm{m}$ in width and MSO measuring $100 \pm 14 \mu \mathrm{m}$ in height and $400 \pm 38 \mu \mathrm{m}$ in width. The cells in this portion were large dense staining multipolar cells, measuring between 17.5 and $25 \mu \mathrm{m}$ in diameter.

At the level of the motor nucleus of the trigeminal nerve, the middle third of the MSO divided into two distinct nuclei as the ventral medial superior olive (VMSO), and dorsal medial superior olive (DMSO) (see Figure 1C). The VMSO appeared like a horse-shoe appearance at this level (see Figure 1D). At this level, the LSO measured

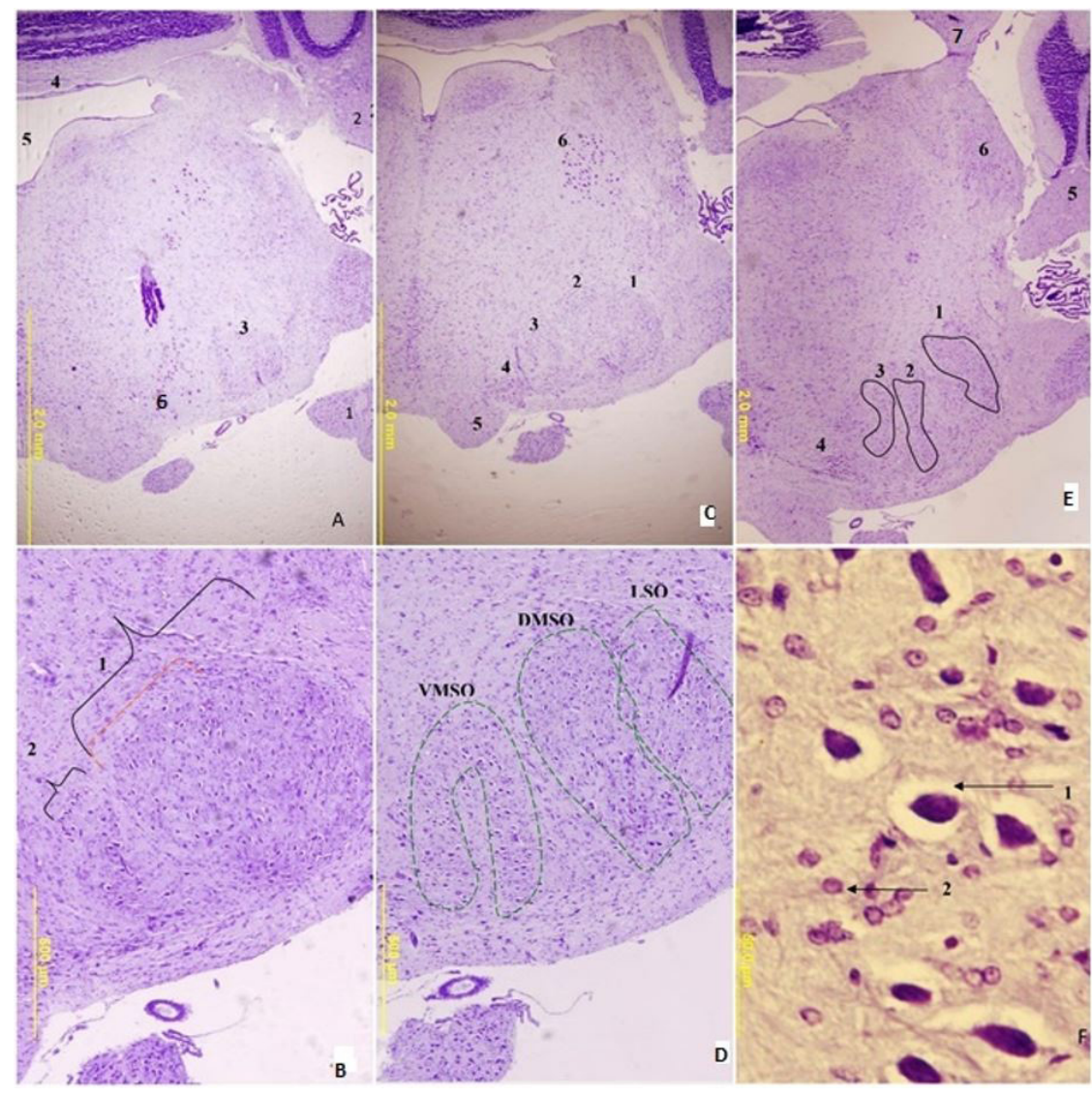

Figure 1. Superior olivary complex of Noctilio leporinus bat. (A) transverse section of the brainstem at the level of the facial nucleus. 1. Cochlear nucleus, 2. Caudal cerebellar peduncle, 3. Superior olivary complex, 4. Cerebellum, 5. Fourth ventricle, 6. Facial nucleus; (B) the divisions of the caudal third of the superior olivary complex in the brainstem. 1. First division of the superior olivary complex (dashed left bracket indicates the folded region), 2. Second division of the superior olivary complex; (C). transverse section of the brainstem at the level of the motor nucleus of the trigeminal nerve. 1. Lateral superior olive, 2. Dorsal medial superior olive, 3. Ventral medial superior olive, 4. Nucleus of the trapezoid body, 5. Pyramids, 6. Motor nucleus of the trigeminal nucleus; (D) the divisions of the middle third of the superior olivary complex. LSO $=$ Lateral superior olive, $\mathrm{DMSO}=$ Dorsal medial superior olive, $\mathrm{VMSO}=$ Ventral medial superior olive; (E) transverse section of the brainstem at the level of the inferior colliculus. 1. Lateral superior olive, 2. Dorsal medial superior olive, 3. Ventral medial superior olive, 4. Nucleus of the trapezoid body, 5. Middle cerebellar peduncle, 6. Lateral lemniscus, 7. Inferior colliculus; (F) the cell-types found in the superior olivary complex. 1. Dark-staining, elongated/multipolar cells, 2. Light-staining round cells measuring $7.5 \mu \mathrm{m}$. 
$350 \pm 25 \mu \mathrm{m}$ in both height and width; while the DMSO measured $50 \pm 6 \mu \mathrm{m}$ in height and $290 \pm 33 \mu \mathrm{m}$ in width and the VMSO, which appeared horse shoe-shaped, $70 \pm 9 \mu \mathrm{m}$ in height and $200 \pm 24 \mu \mathrm{m}$ in width. The cells in all three divisions in this region were found to be mainly large, dense-staining, elongated neurons, measuring between 17.5 and $25 \mu \mathrm{m}$ in diameter (see Figure $1 \mathrm{~F}$ ). As the SOC proceeded rostrally, only the DMSO was predominantly seen and it comprised the same large multipolar, dense-staining cells. However, the number of small round cells increased.

The rostral third of the SOC, at the level of the inferior colliculus, also revealed the three divisions (LSO, VMSO and DMSO) but the VMSO, no longer assuming a horseshoe appearance (see Figure 1E). The VMSO measured $290 \pm 33 \mu \mathrm{m}$ in width and $90 \pm 7 \mu \mathrm{m}$ in height; while the DMSO measured $350 \pm 31 \mu \mathrm{m}$ in width and
$70 \pm 5 \mu \mathrm{m}$ in length and the LSO, $320 \pm 37 \mu \mathrm{m}$ in width, $200 \pm 23 \mu \mathrm{m}$ in height. The LSO, DMSO and VMSO were no longer present at the level of the commissure of the inferior colliculus. The mean body and brain weight of this bat were $48.1 \pm 3.5 \mathrm{~g}$ and $6.93 \pm 0.47 \mathrm{~g}$ respectively.

\subsection{Superior olivary complex of the Phyllostomus hastatus bat}

The SOC first appeared at the level of the facial nucleus and placed lateral to the facial nucleus (see Figure 2A). The caudal third of the SOC divided into LSO and MSO with both areas comprising similar cell types (see Figure 2B). The stromal pattern differentiated one portion from the other. It comprised large, dense-staining, multipolar cells, measuring between 15 and $22.5 \mu \mathrm{m}$ in diameter (see Figure 2B and F).

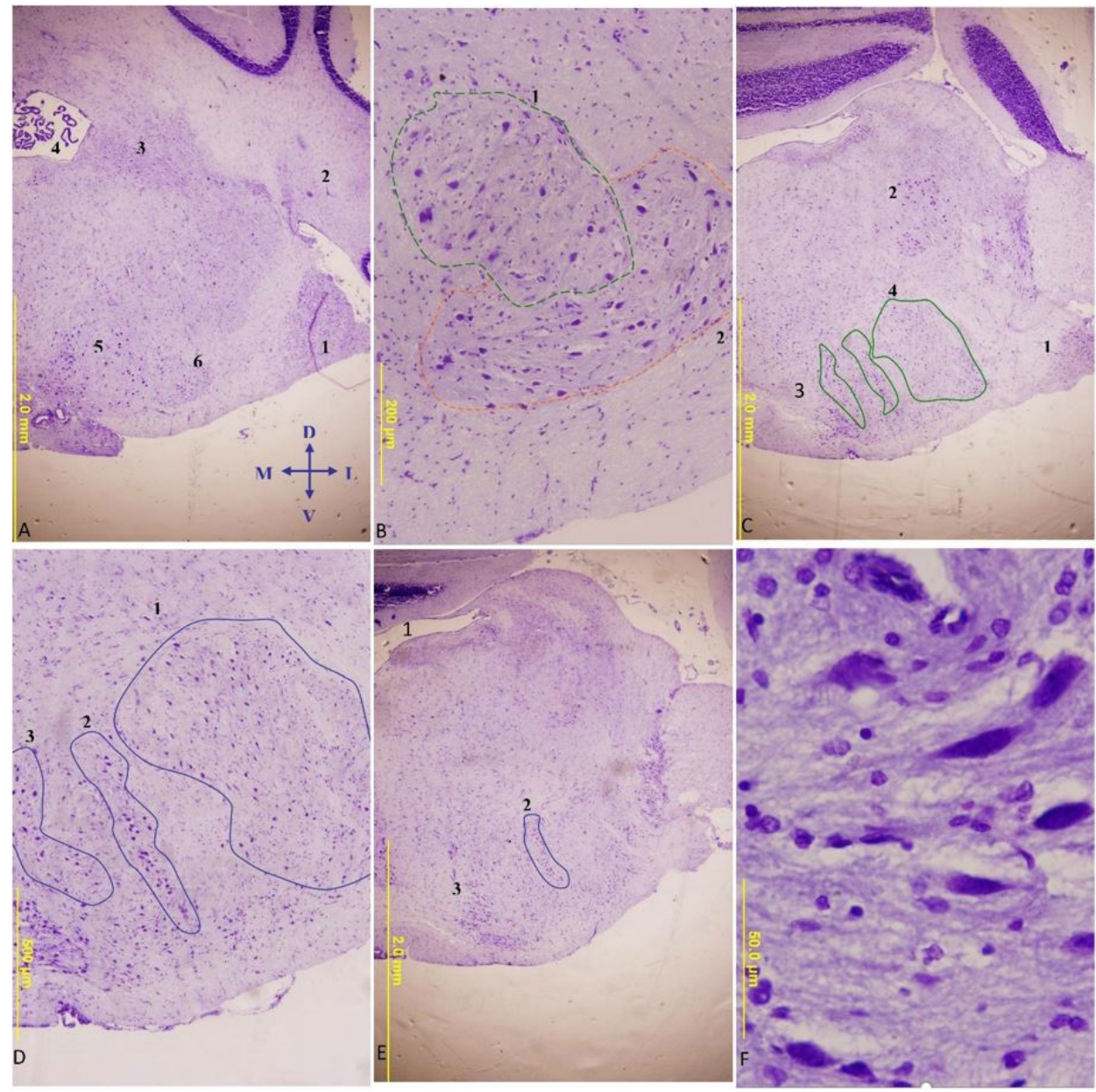

Figure 2. Superior olivary complex of the Phyllostomus hastatus bat. (A) transverse section of the brainstem at the level of the facial nucleus. 1. Cochlear nucleus, 2. Caudal cerebellar peduncle, 3. Medial vestibular nucleus, 4. Fourth ventricle, 5. Facial nucleus, 6. Superior olivary complex; (B) the first (1) and second (2) divisions of the caudal third of the superior olivary complex; (C) transverse section of the brainstem at the level of the trigeminal nucleus. 1. Cochlear nucleus, 2. Trigeminal nucleus, 3. Fourth ventricle, 4. Superior olivary complex; (D) the three (3) divisions of the middle third of the superior olivary complex. 1. Lateral superior olive (LSO), 2. Dorsal medial superior olive (DMSO), 3. Ventral medial superior olive (VMSO); (E) transverse section of the brainstem at the level of the nucleus of the trapezoid body. 1. Fourth ventricle, 2. Dorsal medial superior olive (DMSO), 3. Nucleus of the trapezoid body; (F) the cells found in the superior olivary complex. 
At the level of the trigeminal nucleus, the middle third of the SOC measured $970 \pm 78 \mu \mathrm{m}$ in height and all three divisions, LSO, DMSO and VMSO were now apparent (see Figure 2C and D). At the rostral third at the level of nucleus of the trapezoid body, only the DMSO division was seen (see Figure 2E). No divisions of the superior olivary complex were visible at the level of the inferior colliculus. The total length of SOC measured $480 \pm 50 \mu \mathrm{m}$ in length from rostrocaudally. The mean body and brain weight of this bat were $73.24 \pm 7.25 \mathrm{~g}$ and $8.57 \pm 0.67 \mathrm{~g}$ respectively.

\subsection{Superior olivary complex of the Carollia perspicillata bat}

At the level facial nucleus, the caudal third of the SOC was observed immediately lateral to the nucleus of trapezoid body. It divided into two: lateral and medial portions (see Figure 3A). Both divisions contained medium and large multipolar cells measuring between $12.5 \mu \mathrm{m}$ and $22.5 \mu \mathrm{m}$ in diameter as well as small round cells measuring average diameter of $5 \mu \mathrm{m}$.

The divisions of the middle third of the SOC were very indistinct only at the level of the middle cerebellar peduncle (see Figure 3B). The rostral third of the SOC was located at the level of the inferior colliculus (see Figure 3C) and comprised mainly large multipolar cells, measuring between 20 to $25 \mu \mathrm{m}$ in diameter. The total length of SOC measured $240 \pm 30 \mu \mathrm{m}$ from rostrocaudally. The mean body and brain weight of this bat were $14.4 \pm 2.1 \mathrm{~g}$ and $3.74 \pm 0.75$ g respectively.

\section{Discussion}

The nuclei involved in audition tend to be larger in animals that echolocate and in those with an excellent sense of hearing, compared to other animals (Reis and Erhart, 1979; Casseday et al., 1988). The other auditory nuclei like inferior colliculus, medial geniculate body and cochlear nuclear complex shown significant differences in their size in N. leporinus, P. hastatus, and C. perspicillata bats (Gibbons et al., 2013a, b; Adogwa et al., 2014). SOC displays a significant interspecies variation, being largest in bats and rodents and smaller in primates (Grothe and Park, 2000). The SOC is very well developed in all the bats studied so far. In the present study, the SOC was measured as $640 \pm 70 \mu \mathrm{m}$ in the $N$. leporinus bat, $480 \pm 50 \mu \mathrm{m}$ in the $P$. hastatus and $240 \pm 30 \mu \mathrm{m}$ in the $C$. perspicillata bat. The body and brain weight do not reflect proportionately on the size of the SOC in the present study as the body and brain weight of the $P$. hastatus measured as $73.24 \pm 7.25 \mathrm{~g}$ and $8.57 \pm 0.67 \mathrm{~g}$ respectively which is higher than the $N$. leporinus $48.1 \pm 3.5 \mathrm{~g}$ and $6.93 \pm 0.47 \mathrm{~g}$, but the length of the SOC in P. hastatus $(480 \pm 50 \mu \mathrm{m})$ was lesser than $N$. leporinus $(640 \pm 70 \mu \mathrm{m})$.

The principal nuclei of the SOC of in all three bats in the present study were the lateral superior olive (LSO) and the medial superior olive (MSO), which is similar to the mustached bats (Covey and Casseday, 1995). The principal nuclei of the SOC project to the central nucleus of the inferior colliculus with the lateral superior olive projecting bilaterally and the others projecting to the inferior colliculus ipsilaterally. The different divisions of

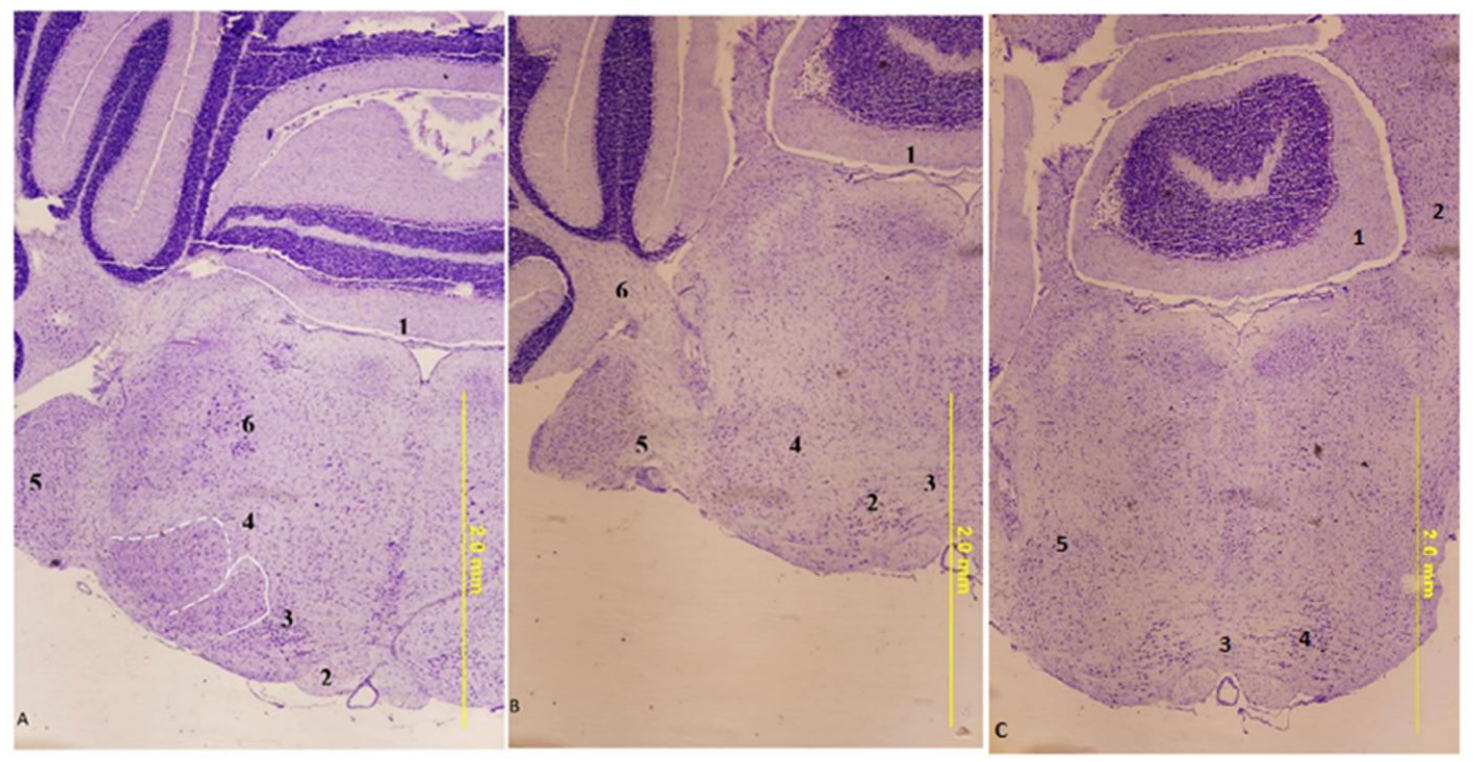

Figure 3. Superior olivary complex of the Carollia perspicillata bat (A) the brainstem at the level of the facial nucleus of the C. perspicillata bat. 1. Cerebellum, 2. Pyramids, 3. Nucleus of the trapezoid body, 4. Superior olivary complex, 5. Cochlear nucleus, 6. Facial nucleus; (B) the brainstem at the level of the middle cerebellar peduncle. 1. Cerebellum, 2. Nucleus of the trapezoid body, 3. Fibres of the trapezoid body, 4. Superior olivary complex, 5. Cochlear nucleus, 6. Middle cerebellar peduncle; (C) the brainstem at the level of the inferior colliculus. 1. Cerebellum, 2. Inferior colliculus, 3. Fibres of the trapezoid body, 4 . Nucleus of the trapezoid body, 5. Superior olivary complex. 
the superior olivary complex received inputs from either the ipsilateral or the contralateral cochlear nucleus (Zook and Casseday, 1982).

The MSO was well-developed in N. leporinus than the other two bats and it further divided into dorsal medial superior olive (DMSO) and ventral medial superior olive (VMSO) in N. leporinus and P. hastatus bats whereas it was less developed in the $C$. perspicillata bats. The variations in the structure of SOC among bats were reflecting varying foraging strategies (Grothe and Park, 2000). The well-developed MSO in N. leporinus can be attributed to the need for high sensitivity to high frequency when these animals forage in open water surfaces and need to detect the water ripples.

In the present study, the subdivisions of MSO were referred to as DMSO and VMSO respectively as stated by Zook and Casseday (1982) in mustached bats rather than MSO and dorsal medial paraolivary olive (DMPO) as it was referred in the Mexican free-tailed bat Grothe et al. (1994). The DMPO showed varying quantities of cell-types with different projection patterns. The fusiform cells were seen in the MSO whereas multipolar cells were seen in the DMPO (Schofield and Cant, 1991; Schwartz, 1977). It was also found that in the free-tailed bat, more than $30 \%$ of the cells of the MSO sent projections to both ipsilateral and contralateral inferior colliculi, whereas these cells sent projections ipsilaterally in other animals (Grothe et al., 1994). In the present study, there was no considerable difference in cell types between these two nuclei, with dark staining multipolar cells occurring predominantly in all three bats.

At the rostral third of the SOC, the VMSO of the $N$. leporinus folded into a horse-shoe shape. No apparent evidence of this occurring in other species of bats or other animals (Rietzel and Friauf, 1998; Helfert and Schwartz, 1986, 1987). The VMSO features that were noted in this study appeared to be equivalent to those of the DMPO (Grothe et al., 1994) in Mexican free-tailed bats. This comparison is based on similar cell-types and location of the nucleus. This VMSO projects to ipsilateral inferior colliculus and receive inputs from the cochlear nuclei (Rietzel and Friauf, 1998; Grothe et al., 1994). This division of the SOC did not appear in the $P$. hastatus and the $C$. perspicillata bats. This difference is probably attributed to the fact that the $N$. leporinus bat uses echolocation as a major part of its feeding strategy (Wenstrup and Suthers,1984; Schnitzler et al., 1994), whereas, $P$. hastatus and C. perspicillata use vision and smell along with echolocation to locate food (Neuweiler, 1989).

The LSO was well developed in $N$. leporinus than the other two bats in this study. The cell population was predominantly the multipolar and elongated cells, which is similar to the multipolar and banana-like cells seen in the LSO of rat, gerbil and cat. These animals use high frequency hearing excellently during foraging due to the well-developed LSO (Rietzel and Friauf, 1998; Helfert and Schwartz, 1986, 1987). Recently however, it has been speculated that the size of the well-developed LSO is more indicative of the animal's overall hearing range rather than sensitivity to high-frequency sounds (Moore, 2000). The cells of the LSO were described as fusiform and bipolar in the ferret and the guinea pig (Rietzel and Friauf, 1998; Helfert and Schwartz, 1986). Generally, the neurons in this area may be either excitatory or inhibitory depending on whether the stimulus is received from the ipsilateral or the contralateral ear, respectively (Schofield and Cant, 1991). The well-developed LSO in N. leporinus used in this study can be attributed to the fact these bats with excellent high-frequency hearing and the overall hearing range than other two bats which helps the $N$. Leporinus to forage effectively over water by various using various echolocation signals. The bats belong to Phyllostomidae family use vision and smell along with echolocation while foraging whereas the bats belongs to Noctilionidae family rely heavily on echolocation for foraging (Neuweiler, 1989). In the present study confirmed the statement of Neuweiler (1989) as the P. hastatus and C. perspicillata are belonging to the Phyllostomidae family whereas the $N$. leporinus belong to the Noctilionidae family. Among the Phyllostomidae family bats, the $P$. hastatus have better developed SOC in the present study than the $C$. perspicillata, which concurs the reports of Hutcheon et al. (2002) that the insectivorous bats rely profoundly on echolocation for the pursuit of and capture of prey than do phytophagous species.

\section{Conclusion}

The principal nuclei of the SOC of in all three bats were the LSO, and MSO. The MSO and LSO are well-developed in $N$. leporinus bats. The MSO of N. leporinus bat subdivided into DMSO and VMSO. The main cell type of cells found in MSO and LSO were dark staining multipolar cells. The well-developed MSO and LSO of N. leporinus bats indicated that these bats were highly sensitive to low frequency sounds and interaural intensity differences, which helped these bats to forage over water by using various types of echolocation signals. The average SOC in $P$. hastatus and C. perspicillata bats can be attributed to the fact that these bats use vision and smell along with echolocation to forage.

\section{Acknowledgements}

The authors thank the University of the West Indies, St. Augustine, Trinidad and Tobago for the financial and infrastructure support for this project.

\section{References}

ADOGWA, A., SUNDARAM, V., GIBBONS, I. and ODEKUNLE, A., 2014. Cytoarchitecture of the medial geniculate body of three species of bats: Noctilio leporinus, Phyllostomus hastatus and Carollia perspicillata. Annual Research \& Review in Biology, vol. 4, no. 3, pp. 460. http://dx.doi.org/10.9734/ARRB/2014/4961.

BAILEY, W.J., SLIGHTOM, J.L. and GOODMAN, M., 1992. Rejection of the "flying primate" hypothesis by phylogenetic evidence from the epsilon-globin gene. Science, vol. 256, no. 
5053, pp. 86-89. http://dx.doi.org/10.1126/science.1301735. PMid:1301735.

CASSEDAY, J.H., COVEY, E. and VATER, M., 1988. Connections of the superior olivary complex in the rufous horseshoe bat Rhinolophus rouxi. The Journal of Comparative Neurology, vol. 278, no. 3, pp. 313-329. http://dx.doi.org/10.1002/cne.902780302. PMid:2464005.

COVEY, E. and CASSEDAY, J.H., 1995. The lower brain stem auditory pathway. In: A.N. POPPER and R.R. FAY, eds. Hearing by bats. New York: Springer Verlag, pp. 235-296. http://dx.doi. org/10.1007/978-1-4612-2556-0_6.

GENOUD, M., BONACCORSO, F.J. and ANENDS, A., 1990. Rate of metabolism and temperature regulation in two small tropical insectivorous bats (Peropteryx macrotis and Natalus tumidirostris). Comparative Biochemistry and Physiology. Part A, Physiology, vol. 97, no. 2, pp. 229-234. http://dx.doi. org/10.1016/0300-9629(90)90177-T.

GIBBONS, I., ADOGWA, A., VENKATESAN, S., ISITOR, G.N. and ODEKUNLE, A., 2013a. The cytoarchitecture of the cochlear nuclear complex of two species of bats: Carollia perspicilliata and Phyllostomaus hastatus. European International Journal Science of Technology, vol. 2, no. 8, pp. 226-234

GIBBONS, I., SUNDARAM, V., ADOGWA, A. and ODEKUNLE, A., 2013b. The cytoarchitecture of the inferior colliculus of two species of bats: Noctilio leporinus (Fish Eating) and Phyllostomus Hastatus (Carnivorous/ Omnivorous). International Journal of Life Science and Medical Research, vol. 3, no. 4, pp. 173-178. http://dx.doi.org/10.5963/LSMR0304005.

GLENDENNING, K.K. and MASTERTON, R.B., 1998. Comparative morphometry of mammalian central auditory systems: variation in nuclei and form of the ascending system. Brain, Behavior and Evolution, vol. 51, no. 2, pp. 59-89. http:// dx.doi.org/10.1159/000006530. PMid:9491274.

GLENDENNING, K.K., HUTSON, K.A., NUDO, R.J. and MASTERTON, R.B., 1985. Acoustic chiasm II: anatomical basis of binaurality in lateral superior olive of cat. The Journal of Comparative Neurology, vol. 232, no. 2, pp. 261-285. http:// dx.doi.org/10.1002/cne.902320210. PMid:3973093.

GROTHE, B. and PARK, T.J., 2000. Structure and function of the bat superior olivary complex. Microscopy Research and Technique, vol. 51, no. 4, pp. 382-402. http://dx.doi.org/10.1002/10970029(20001115)51:4<382::AID-JEMT7>3.0.CO;2-7. PMid:11071721.

GROTHE, B., SCHWEIZER, H., POLLAK, G.D., SCHULLER, G. and ROSEMANN, C., 1994. Anatomy and projection patterns of the superior olivary complex in the Mexican free-tailed bat, Tadarida brasiliensis mexicana. The Journal of Comparative Neurology, vol. 343, no. 4, pp. 630-646. http://dx.doi.org/10.1002/ cne.903430412. PMid:8034792.

HELFERT, R.H. and SCHWARTZ, I.R., 1986. Morphological evidence for the existence of multiple neuronal classes in the cat lateral superior olivary nucleus. The Journal of Comparative Neurology, vol. 244, no. 4, pp. 533-549. http://dx.doi.org/10.1002/ cne.902440409. PMid:2420837.

HELFERT, R.H. and SCHWARTZ, I.R., 1987. Morphological features of five neuronal classes in the gerbil lateral superior olive. The American Journal of Anatomy, vol. 179, no. 1, pp. 55-69. http://dx.doi.org/10.1002/aja.1001790108. PMid:3618521.

HUTCHEON, J.M., KIRSCH, J.A.W. and GARLAND JUNIOR, T.A., 2002. Comparative analysis of brain size in relation to foraging ecology and phylogeny in the Chiroptera. Brain, Behavior and Evolution, vol. 60, no. 3, pp. 165-180. http:// dx.doi.org/10.1159/000065938. PMid:12417821.
MOORE, D.R., 2000. Auditory neuroscience: is speech special? Current Biology, vol. 10, no. 10, pp. 362-364. http://dx.doi. org/10.1016/S0960-9822(00)00479-6. PMid:10837214.

NEUWEILER, G., 1989. Foraging ecology and audition in echolocating bats. Trends in Ecology \& Evolution, vol. 4, no. 6, pp. 160-166. http://dx.doi.org/10.1016/0169-5347(89)90120-1. PMid:21227342.

REIS, P.F. and ERHART, A.E., 1979. The brain of the marmoset (Callithrix jacchus). Acta Anatomica, vol. 103, no. 3, pp. 350-357. http://dx.doi.org/10.1159/000145034. PMid:107717.

RIETZEL, H.J. and FRIAUF, E., 1998. Neuron types in the rat lateral superior olive and developmental changes in the complexity of their dendritic arbors. The Journal of Comparative Neurology, vol. 390, no. 1, pp. 20-40. http://dx.doi.org/10.1002/ (SICI)1096-9861(19980105)390:1<20::AID-CNE3>3.0.CO;2-S. PMid:9456173.

SANES, D.H., 1990. An in vitro analysis of sound localization mechanisms in the gerbil lateral superior olive. The Journal of Neuroscience, vol. 10, no. 11, pp. 3494-3506. http://dx.doi. org/10.1523/JNEUROSCI.10-11-03494.1990. PMid:2172478.

SCHNITZLER, H.U., KALKO, E.K.V., KAIPF, I. and GRINNELL, A.D., 1994. Fishing and echolocation behavior of the greater bulldog bat, Noctilio leporinus, in the field. Behavioral Ecology and Sociobiology, vol. 35, no. 5, pp. 327-345. http:// dx.doi.org/10.1007/BF00184422.

SCHOFIELD, B.R. and CANT, N.B., 1991. Organization of the superior olivary complex in the guinea pig. I. Cytoarchitecture, cytochrome oxidase histochemistry, and dendritic morphology. The Journal of Comparative Neurology, vol. 314, no. 4, pp. 645670. http://dx.doi.org/10.1002/cne.903140403. PMid:1726174.

SCHOFIELD, B.R., 2002. Ascending and descending projections from the superior olivary complex in guinea pigs: different cells project to the cochlear nucleus and the inferior colliculus. The Journal of Comparative Neurology, vol. 453, no. 3, pp. 217-225. http://dx.doi.org/10.1002/cne.10402. PMid:12378584.

SCHWARTZ, I.R., 1977. Dendritic arrangements in the cat medial superior olive. Neuroscience, vol. 2, no. 1, pp. 81-101. http://dx.doi.org/10.1016/0306-4522(77)90070-7. PMid:917277.

SPITZER, M. and SEMPLE, M.N., 1995. Neurons sensitive to interaural phase disparity in gerbil superior olive: diverse monaural and temporal response properties. Journal of Neurophysiology, vol. 73, no. 4, pp. 1668-1690. http://dx.doi.org/10.1152/ jn.1995.73.4.1668. PMid:7643174.

VON DER EMDE, G. and SCHNITZLER, H.U., 1990. Classification of insects by echolocating greater horseshoe bats. Journal of Comparative Physiology, vol. 167, no. 3, pp. 423-430. http://dx.doi.org/10.1007/BF00192577.

WEBSTER, W.R., DAY, R.H., GILLIES, O. and CRASSINI, B., 1992. Spatial-frequency-contingent color aftereffects: adaptation with two-dimensional stimulus patterns. Perception \& Psychophysics, vol. 51, no. 1, pp. 66-78. http://dx.doi.org/10.3758/ BF03205075. PMid:1549426.

WENSTRUP, J.J. and SUTHERS, R.A., 1984. Echolocation of moving targets by the fish-catching bat, Noctilio leporinus. Journal of Comparative Physiology, vol. 155, no. 1, pp. 75-89. http://dx.doi.org/10.1007/BF00610933.

ZOOK, J.M. and CASSEDAY, J.H., 1982. Origin of ascending projections to inferior colliculus in the mustache bat, Pteronotus parnellii. The Journal of Comparative Neurology, vol. 207, no. 1, pp. 14-28. http://dx.doi.org/10.1002/cne.902070103. PMid:7096636. 